\title{
Kantian and Utilitarian Ethics on Capital Punishment
}

\author{
Mfonobong David Udoudom ${ }^{1}$, Samuel Akpan Bassey², Okpe², Timothy Adie ${ }^{2}$ \\ ${ }^{1}$ Social Science Unit, School of General Studies, University of Nigeria, Nsukka, Nigeria. \\ ${ }^{2}$ Department of Philosophy, University of Calabar, Calabar, Cross River, 540242, Nigeria
}

\begin{abstract}
It is an indisputable fact that most societies in the world agrees that if a person violates the laws, he/she should be penalized. However, the variations appear when it involves what sensibly punishment ought to be applied, predominantly for major crimes like murder. Death penalty, which as well referred to as execution or capital punishment, is one amongst these variations which have caused several arguments and debates between its opponents and supporters. Today, numerous countries are attempting to seek out different sanctions for major crimes like life imprisonment relatively to capital punishment. This research tries to take a look at the idea of capital punishment from Kantian and Utilitarian ethics perspectives.
\end{abstract}

Keywords : Ethics; Kantian; Utilitarian; Capital Punishment.

\section{Introduction}

Death penalty is one of the most severe of punitive consequences, with its appliance representing the utmost of finalities in law enforcement and criminal sentence. An issue which has garnered intense debate for decades and which has divided individuals along party lines and philosophical dispositions, the use of capital punishment is defended by its activists as an effective way to discourage violent crime and as a critically effective way to punish the worst of offenders. Its critics regard it as unconstitutional, barbaric or generally a violation of human rights. Nigeria is one of few democratic countries in the world which still employs the death penalty in its criminal justice system. This conversation will examine the death penalty from a number of perspectives in order to assess the ethical accuracy of its use. Addressing the concept of death penalty first as a policy, and subsequently, applying the Kantian and Utilitarian models to the policy, the argument will be designed to demonstrate that Nigerian use of the death penalty within the context of its legal system is ethically wrong.

\section{Review of Literature}

\subsection{The Death Penalty as A Policy}

It is the legal position that the death penalty is Constitutional in Nigeria and even in the United States. Accordingly, Reid (2004) reports that "capital punishment is obviously the most severe of all sentences the government imposes. The U.S. Supreme Court has interpreted the Constitution as placing some limitations on the punishment, but in 1972 in Furman v. Georgia the Court held that capital punishment is not per se unconstitutional although it was found to be so in that case." (Reid, 536)

Both countries Supreme Court have repeatedly confirmed the necessity of the death penalty as a tool for law enforcement and punitive retribution. This is vital because it is underscored by a Constitutional theory that is proposed to reflect an ethical balance of justice and mercy. With great conviction, ethical rightness is a part to every judicial assessment of capital punishment. An illustration is provided to the research by The British Medical Journal (1950) which serves as a major source on the debate during the middle of the $20^{\text {th }}$ Century regarding the state's ability to function as an arbiter of ethicality while carrying out the death penalty. More specifically, the article investigates the treatment of insanity, mental 
instability and impairment in the capacity to differentiate between right and wrong. Ultimately, it grants that government has essentially assumed the capacity to detect that such conditions are present and to use these as conditions by which to not apply the death penalty. The article reports that "concerning the investigation of the mental condition of murderers, Dr. Rowland Hill said that it was considered that the present procedure of the courts was satisfactory, provided that the defense had an opportunity of carrying out a complete investigation of the prisoner's state of mind." (Capital Punishment, 368) This idea suggests significantly that there is cause for ethical scrutiny on the part of lawmakers and judges. Suggesting the psychological nature of the convicted murdered plays into a moral assessment of the nature and severity of the proposed punishment indicates that for those who assess the appropriateness of the death penalty, there are effectors other than the brutality of the crime which enter into the design of proper retribution. Moreover, in this instance it is contended that the rights of the accused must enter into this ethical quandary, reflecting this Constitutional imperative toward ethical carriage of justice.

It is thus that more recently, the ability of legislative and judicial agents to evaluate ethical rightness is being called into question, with larger segments of the public, the legal community and even among public office-holders recognizing that imperfections in the legal system have caused deed flawed practice.

This position seems to underscore some of the clear ethical arguments against the use of the death penalty, particularly its arbitrary nature, which renders it as an instrument of punitive enforcement that is subject to the economic, racial and political peculiarities of the judiciary system. A major cause to question the ethical legitimacy of the death penalty may be related to inherent biases in our judicial system which seems directly to implicate racial and socioeconomic prejudices in the deliberation of justice. Persistent claims as to the conditional proclivity for African Americans, for instance, to be unfairly treated by the judicial system proposes a reason for the public's ethical wariness of this intractable approach. Today, the death penalty is deeply disputed in the courts under these pretenses. Reid depicts this as an issue of public policy and public opinion alike, demonstrating that

"there has been a growing demand for a moratorium on capital punishment, led by Illinois governor George Ryan, who in 2000 declared that state's moratorium after 13 death row inmates were exonerated ... Ryan granted four pardons to Illinois death row inmates and commuted to life the sentences of the remaining ones before he left office in 2003. His successor continued the moratorium. Ryan made his decision because of the questions of fairness with regard to the use of this severe punishment." (Reid, 536)

This means that for Governor Ryan, the scintilla of doubt-and in some cases much more than a scintilla was available. It also denotes a terrible inconsistency in a mode of punishment which once carried out could not be reversed. The collapse which this reveals of the justice system in carrying out a punishment with an supreme authority when is not able to guarantee an absolute rightness of the judicial process is vital for our deliberation beneath both the Kantian and Utilitarian models of thought.

Additionally, this aspect of the discussion represents what is more consistently emerging as positive recognition that institutional racism has contributed to a serious danger in implementing the death penalty. The political history of the United States as a deeply unequal and racially imbalanced nation is evidenced in their law enforcement, judicial realities and prisons, where those of disadvantaged races are most significantly impacted. 
This illustrates the clear connection between the implementation of the death penalty and the enforcement of negative political patterns in U.S. society and culture, a direct counterpoint to the ethical intentions of the Constitution and legal system.

The system is seen as woefully inefficient as well. In the article by Powell, the author reveals the implementation of the death penalty to be mired in bureaucratic lag time and an inherent impediment on the carriage of justice which is imposed by uncertainty in the accountability of the punishment. Powell points to the actuality that "in Georgia, for example, the time between the date of the murder and the murderer's execution (if it occurs) averages close to I0 years 25. Although the average lapsed time in Georgia may be the highest, the same situation generally prevails in a number of other states. No one would suggest that this is satisfactory." (Powell, 1038)

Indeed, it demonstrates a process which is crowded with rational causes to delay in the implementation, primarily because the application of the death penalty is so difficult to evaluate ethically. The extent of doubt which has been cast upon the fairness, efficiency or consistency of the death penalty is adequate to warrant a query on its ethical rationality. In many ways, those perspectives which have supported its unquestioned usage tend to align philosophically with authoritarian state structures, connectivity between the legitimacy of state and the certainty of theologies, and a steadfast confidence in the social contract between state and her citizen. This is echoed in John Locke's view, which is that

"the political power which gives the state the right to impose the death penalty stems from the natural rights which all people possess in the state of nature. In that state the one who transgresses against the laws of nature departs from the rule of reason and puts himself into a state of war with other members of society. Consequently those other members have a right to protect themselves as well as others against the transgressor, and this right of self-protection includes the right to kill the transgressor." (Calvert, 211-212)

In spite of the wide range of practical and ethical causes to question this, the view acknowledged above seems to persist as the most defining philosophical outlook of many adheres who perceives themselves as being inherently in the position to carry out this intractable penalty.

\subsection{Kantian Ethics}

In our analysis here of the various possible lenses through which we can understand ethical morality. Immanuel Kant's theory provides a socially constrained, rigid and sometimes dangerous absolutism through which to grasp the death penalty.

At the core of Kant's argument is the assertion that the same reason which applies to the empirical nature of scientific discourse should rationally apply in the same way to ethical discourse. Kant claims that "physics will have its empirical part, but it will also have a rational one; and likewise ethics - although here the empirical part might be called specifically practical anthropology, while the rational part might properly be called morals." (Kant, 20) To Kant, ideals on ethical autonomy are intimidating to social order, representing the opportunity for an individual to devise his own ethical parameters. The rationality of scientific reasonableness denotes, to Kant, instead a heteronymous orientation whereby there is an umbilical cord of ethicality common to all women and men, directing and restraining behaviors. Kant sees autonomy as the capacity to act based on one's own volition. Heteronomy, on the other hand, is a general set of social forces inclining people to be apt 
toward common motives and common actions.

Accordingly, Kant lays out a brief framework for justice, which Singer says "has traditionally been though of as issuing in 'categorical imperatives,' which take no account of individual situations, personal differences or extenuating circumstances. Thus Kant has effectively been stereotyped as an ethical absolutists . . one who holds that, for example, it is always wrong to lie, no matter what the circumstances or consequences." (Singer, 577)

The 'categorical imperative' in which Kant alludes to is initial to the normative hypothesis which suggests that there are some undeniable force connected with our formation and actualization of 'good' or 'evil.' It persuades us to understand that the means by which we act are intrinsically informed by our dedication to a single, unchanging and shared idea concerning what is right. To consign to this idea is practical reason and to fall short on this obligation is irrational, which allows Kant to suggest that such a positive connection could be observed between morality and rationality. This also allows Kant to attribute a steadfast degree of support to state structures, which he suggest as having an inherent need to enforce an order which is best for the common good. Thus, its duty in Kant's perception to enforce without wavering the standards of good and evil which are consistent with the categorical imperative. To this, Kant "suggests at one point the law should be designed so that a race of devils could live in peace under it. The rules of punishment are inflexible and tough: all the guilty must be punished, made to suffer the equivalent of the losses they inflicted, and there should be no pardon for public crimes." (Hill, 408)

If Kant's points are to be integrated when accepting a moral position on punishment, such whole terms are unavoidably defined by governing social structures. The inextricable association which economy, theology, morality and society have in common all through history tends to have a substantial impact on the way these hegemonic principles are defined. Kant rejects any elasticity outright, which in a sense that critic has held on, revealed a thinker deeply enamored of his own principles. So notes the article by Merle (2009), which relates that "most of these mixed theories represent an effort by deontological, especially Kantian philosophers to break with the traditional view of the deontological, especially Kantian justification of punishment as a thoroughly retributivist theory. Indeed, it is with good reason that such a theory has been suspected of relying more on private morality than on principles of right" (Merle, 311) . This idea of personal morality as being present in a philosophy which otherwise imposes itself on a group becomes troubling when it is applied to death penalty.

\subsection{Utilitarian Ethics}

The above can be contrast to the idea of utilitarianism, which proposes that all situations demand a certain degree of pragmatism with regards to behavior. This throws into disarray the moral presuppositions of Kant, with such thinkers as John Stuart Mill and Jeremy Bentham coming to the fore of the conversation. In utilitarian philosophy, it is essential that morality be channeled through an understanding of context and the nuances of society on human relations. Bentham rejects the simple notion that there are certain guaranteed natural rights to which all men are permitted and should as a result be rewarded by the virtue of their existence, premising on the value from a utilitarian perspective. He rejected the idea that any group or individual should be given an ethical framework through which he or she could then dictate that which is right and wrong. This, Bentham contends, would be a negation to the preservation of individual rights. Far too many insubstantial factors enter into any given 
ethical dilemma. So denotes Bedau (1983), who reports that "as commentators on utilitarianism have made clear,22 any possible utilitarianism is some combination of (i) a doctrine of the end-state to be realized, that is, a condition or state of affairs deemed to have intrinsic value, and (ii) a theory of the consequences of possible actions open to the agent (person, legislature, society), whose value is purely instrumental because choice among these alternative actions is determined by how efficiently each leads (or would lead) to the endstate." (Bedau, 1037)

This means that such absolutism as reflected in the categorical imperative is destined to lead to an oversight of these nuances and variations. The prescription for an ethical outcome will be based on uniformity with utilitarianism claims to be fundamentally irrational. There is a responsibility on the part of those charged with public leadership of extending the greatest good and preventing the harm where possible. This symbolizes a social platform for the creation of ethical decisions which proceeds from any number of variables. As Harsanyi (1977) indicates, "in any utilitarian theory, maximization of 'social utility' (or of the total amount of 'good' in our social environment) plays a fundamental role. Yet, this 'social utility' has been defined by diverse utilitarians in different ways. The classics of utilitarianism used a hedonistic definition: they measured social utility to be the total amount of pleasure - less the total amount of pain - if each instance of pleasure and of pain is properly weighted according to its duration, intensity, and similar characteristics." (Harsanyi, 27) This contributes to utilitarian conceptions of crime and punishment which seek to provide some measure of pragmatic examination of the context, conditions and social utility which are present in any ethical transgression.

\section{Discussion}

\subsection{Kantian Ethics on the Death Penalty}

In applying Kant's ideas to the matter of capital punishment, it is clear that he is a definitive advocate for this level of state authority. Kant takes the position that the construction of ethicality around moral absolutes of good and evil denotes the need for strong social control of those that would deviate. This also defines an expectation of the state or authority as having achieved a superior position on morality by being granted this power. Essentially, Kant would hold that "the system of law needs to be guaranteed against the inclination of citizens to break the law, and that it obtains this guarantee by threatening them. Thus deterrence is the fulfillment of the public right of coercion. But once the finality of punishment is defined in this way, the execution of punishment, i.e. its type and degree, no longer follows the deterrence principle. Rather, it follows the retribution principle" (Merle, 313)

Kant's theories, critics contend, strikes something of a hybrid between an interest in retribution and deterrence, with both following the logic that overwhelming state authority is the antidote to unethical behavior. Kant's categorical imperative instructs that those who have transgressed against the universally accepted norms of good and evil have ceded their rights and are thus at the mercy of the state. In the interest of protecting its law-abiding citizenry, Kant would argue, the state may be seen as therefore requiring of such an instrument as the death penalty. This allows for an instrument that enables both a formidable deterrent to the commitment of crime and a manner of retribution which some would argue is equivalent to certain crimes. 
Ultimately, Kant's position follows a logic which entitles almost limitless power to state structures in enforcing moral imperatives which are said to be clear and self-evident. Therefore, we can see that Kant's "reasoned approach to the death penalty presupposes a comprehensive theory of punishment. A comprehensive theory of punishment is an account of punishment which distinguishes it from arbitrary and unjust violence and which, in doing so, provides a criterion for the legitimate deprivation of rights." (Brudner, 337) Referring back to the idea offered by Locke, we can see here the idea that the very status of the government is what permits it such a broad set of liberties in enforcing its will.

\subsection{Utilitarian Ethics on the Death Penalty}

Of course, this is the type of ideology which instills discomfort in utilitarian's, who may be said to fear the capacity of governments and authorities to exploit personal biases on good and evil for personal gain or the retention of status. Essentially, the danger of overempowering governments suggests a utilitarian aversion to such intractable instruments as the death penalty. Indeed, "from a utilitarian standpoint the death penalty is difficult to justify. The statistical evidence fails to confirm (though neither does it decisively refute) the common intuition that capital punishment deters potential murderers and protects society from actual ones more effectively than incarceration for life. It is true that no study of the deterrent effect of capital punishment can be conclusive, since it is impossible to compare the effects of retention and abolition within the same jurisdiction over the same time period." (Brudner, 338)

That said, so many arguments in favor of the death penalty have hinged on the certainty that it must be a deterrent. So is this noted as half the motive for Kant's certainty on such issues as the death penalty. Invoking Bentham here, we can actually see that the utilitarian view prescribes a mode for evaluating the appropriate punishment that demands deterrence. Bedau (1983) opines that "according to Bentham, a punishment, like any other legal practice, must be morally justified in terms of its conduciveness to the appropriate end. That end can be variously stated, and Bentham's own account of it varies depending on whether he has approximate or the ultimate end in mind. 'The immediate principle end of punishment,' he writes, is to 'control action,' the conduct of those who are liable to a punishment if they violate the law as well as the conduct of those who are undergoing punishment after having been sentenced for a violation." (Bedau, 1038) This means that where there is a lack of evidence that a method serves as a deterrent, it may be called into question as a viable way to enforce the law.

This is only further compounded in the case of the death penalty by the wide range of factors revealed in the first section of this account, which demonstrate it to be a punishment subjected to far too many intangibles, variables and speculative doubts to be perceived as ethical in the utilitarian perspective. Quite to the contrary, the utilitarian view would hold that in the absence of certainty, pragmatic application speaks to the wrongness of the death penalty. For instance, the uncertainty that is reported in terms of the racial and socioeconomic imbalance of our legal system suggests a potential to invoke harm through state controlled channels rather than mollifying the harm committed by criminal behavior. Brudner (1980) supports this perspective by remarking upon the doubt surrounding the efficiency, effectiveness and accountability of the death penalty as being sufficient to doubt its ethicality. As Brudner would indicate, "since the burden of justification rests with those who would take 
a life, inconclusive data to in favour of abolition." (Brudner, 338) This also helps to define the position ultimately taken in our research.

The clear bias presented in this text proceeds from the fundamental practicality of the utilitarian view and, by contrast, is compelling otherwise by the inherent prejudice driving the Kantian perspective.

\section{Conclusion}

Guided by the central principle that morality may defined as the creation, extension or preservation of happiness for the largest number of people at all times, Bentham and Mill's ideas are theoretically antithetical to Kant's commitment to absolute morality. Where Kant presents the argument that moral order is impossible to define without permanent standards that are shaped by manmade system's such as government, utilitarianism works within a system that must inherently be pragmatic. The flexibility of this approach asserts that one must consider this balance before making an ethically informed decision in any regard. This is a markedly valuable perspective where capital punishment is concerned, offering the type of philosophical scrutiny that is justified where the outcome is as weighty as a man's life. By contrast, Kant allows for none of this measuring of variables, instead indicating that where the law correlates an act of crime with a specific form of punishment, little must be discussed ethically. The very source of capital punishment, being from the state authorities, is sufficient to ethically validate any decree in Kant's view.

Given the way that so many government's past and present have demonstrated themselves as being anything from flawed to tragically corrupt, this trust seems deeply and problematically misplaced. The inherent biases in the American legal system, for a primary example, produce a system which is unequal based on such factors as race and socioeconomic status. If the death penalty is an extension of this system-and most evidence relayed in this discussion confirms that such is the case - then it becomes an act of evil executed by the state.

Clearly, the nature of the Constitution and the construction of justice suggests that the intent is to protect law-abiding citizens while maintaining a balance of fair treatment. It has fallen somewhat short of these ambitions due to a commitment to values such as those explicated by Locke and Kant. Quite certainly, the discourse on capital punishment could benefit from a stronger insertion of utilitarian theories. These would ultimately demand a hard look at the institution and such factors as social, economic and legal norms in relation to ethicality. That any such scrutiny would find gross corruption, inequality and inefficiency in the system indicates that the United States government hasn't the ethical authority to determine who should live and who should die by its hand.

\section{References}

Bedau, H. A. (1983). Bentham's Utilitarian Critique of the Death Penalty. The Journal of Criminal Law and Criminology, 74(3), 1033-1065. Retrieved November 8, 2009, from http://www.jstor.org/stable/1143143

Brudner, A. (1980). Retributivism and the Death Penalty. The University of Toronto Law Journal, 30(4), 337-355. Retrieved November 08, 2009, from http://www.jstor.org/stable/825562 
Calvert, B. (1993). Locke on Punishment and the Death Penalty. Philosophy, 68(264), 211 229. Retrieved November 07, 2009, from http://www.jstor.org/stable/3751163

Capital Punishment. (11,1950). The British Medical Journal, 1(4649), 365-369. Retrieved November 08, 2009, from http://www.jstor.org/stable/25375103

Harsanvi, J. C. (1977). Rule Utilitarianism and Decision Theory. Erkenntnis, Social Ethics, 11(1), 1st ser., 25-53. Retrieved November 08, 2009, from http://www.jstor.org/stable/20010532

Hill Jr., T. E. (1973). The Hypothetical Imperative. The Philosophical Review, 82(4), 429450. Retrieved November 08, 2009, from http://www.jstor.org/stable/2183709

Kant, I., \& Gregor, M. J. (1996). Groundwork of the Metaphysics of Morals (1785). Practical Philosophy, 37-108. http://doi.org/10.1515/9783110204551

Merle, J. (2009). A Kantian Critique of Kant's Theory of Punishment. Law and Philosophy, 19(3), 311-338. Retrieved November 07, 2009, from http://www.jstor.org/stable/3505178

Powell, Jr., L. F. (1989). Capital Punishment. Harvard Law Review, 102(5), 1035-1046. Retrieved November 08, 2009, from http://www.jstor.org/stable/1341469

Reid, Sue T. (2004). Criminal Law. 6th ed. New York: McGraw-Hill. Print.

Singer, M. G. (1954). The Categorical Imperiative. The Philosophical Review, 63(4), 577591. Retrieved November 08, 2009, from http://www.jstor.org/stable/2182292 